\title{
Correlation and Path Coefficient Analysis of Grain Yield and its Growth Components in Soybean (Glycine max. L.)
}

\author{
Agashe Nehatai Wamanrao ${ }^{*}$, Vinod Kumar ${ }^{2}$ and Dronkumar Meshram ${ }^{3}$ \\ ${ }^{1}$ Department of Mathematics, Statistics \& Computer Science, G. B. Pant University of \\ Agriculture and Technology, Pantnagar, Uttarakhand, India \\ ${ }^{2}$ Department of Agronomy, Dr.PanjabraoDeshmukhKrishiVidyapeeth Akola, India
}

*Corresponding author

\section{A B S T R A C T}

Keywords

Correlation; Path

Coefficient;

Biological yield

Article Info

Accepted:

20 February 2020

Available Online:

10 March 2020
In this paper, correlation and path coefficient analysis for finding all possible relationships between grain yield and plant growth components have been carried out. The plant growth components are not only individually correlated with yield, but also correlated among themselves. The inter-character correlations among grain yield (GY), number of grain per plant (NG), number of pods per plant (NP), leaf area index (LAI), plant height $(\mathrm{PH})$, weight of grain per plant (WG), number of branches per plant and biological yield (BY) were measured for this study. The correlation analysis reveals that the number of pods per plant $\left(0.649^{* *}\right)$, the number of grains per plant $\left(0.592^{* *}\right)$ and the number of branches per plant $\left(0.798^{* *}\right)$ are significantly correlated with grain yield. Among the causal characters, the number of branches per plant exhibits the highest direct positive effect (0.797) with grain yield. Finally, it is concluded that the number of grain per plant, number of branches per plant and number of pods per plant should be considered as indices for selecting high yielding soybean variety.

\section{Introduction}

Soybean (Glycine max.L.) is very important oilseed crop of legume family which contributes to $25 \%$ of the global edible oil (Agarwal et al., 2013). It is a 'miracle golden bean' of the $21^{\text {st }}$ century. It is an excellent source of protein, oil, high level of amino acids such as lysine, linolenic, lecithin and large amount of phosphorous. It contains approximately $40-45 \%$ protein and $18-22 \%$ oil and is a rich source of vitamins and minerals. It is world's first ranked crop as a source of vegetable oil.

Therefore, it is considered in the category of most valuable agronomic crops in the world. Information of inter-relationship among plant 
growth components and grain yield is essential for improvement of crop production. The concept of path coefficient analysis was originally developed by Sewall Wright in 1921. Path coefficient method was first used by Dewey and Lu (1959) for plant selection in Crested Wheatgrass.

The plant growth components are not only individually associated with yield, but also associated among themselves. Plant growth components may influence productivity of grain yield. The growth components that are strongly correlated with soybean grain yield include the number of pods per plant, number of grains per pod and the mass of one thousand grains (Mauricio et al., 2018).

Aondover et al., (2013) also estimated the correlation coefficient and path analysis and observed that seed yield show significant positive correlation with pods per plant. The path analysis is essential technique to estimate the direct and indirect effect of growth component on soybean grain yield [Mauricio et al., 2018].

Path Coefficient analysis separates the direct influence of a particular variable on the response variable and the effects of the variable through other variables [Arshad et al., (2006)]. Path coefficient analysis or simply path analysis is the special type of multiple regression analysis based on assumption of linearity and additivity.

Johnson at el. (1995) described the genotypic and phenotypic correlations for grain yield and yield variables in wheat. Cyprien and Kumar (2011) carried out path coefficient analysis of rice cultivars data and observed that the panicle number and panicle weight were high positive direct effects on the grain yield.

Sohel at el (2016) estimated inter-relationship between plant growth components and grain yield of black gram genotypes and observed that the biomass plant ${ }^{-1}$ followed by pods plant $^{-1}$ and seeds pod ${ }^{-1}$ had maximum positive direct effect on grain yield. Magashi et al., (2018) observed the association among some qualitative characters of different varieties of Soybean in the Sudan Savannah region.

Dvorjak et al., (2019) conducted experiment to estimate the phenotypic and genotypic correlations between agronomic characters and perform a path analysis in order to identify growth components for indirect selection of high grain yielding variety of soybean crop.Patil and Deshmukh (1989) and Iqbal et al., (2003) also described the use of path analyses in blackgram breeding.

Udensi and Ikpeme (2012) conducted experiment on pigeon peato know the extent of relationship between yield and its components. They observed significant positive correlations between plant height per plant and number of leaves per plant $(0.926 * *)$, leaf area plant $(0.574 *)$ and number of seeds per plant $\left(0.616^{*}\right)$ with grain yield.Shamsi (2009) analyzed the effects of plant density on yield components, grain filling and yield of chick pea.

Study indicated that the no. of nodes per main stem, number of branches per plant and the harvest index were affected by density. Steve et al., (2019) carried out path analysis of maize hybrid yield and growth variables across planting dates.

The object of study is to carry out correlation and path coefficient analysis for finding all possible relationships between grain yield and plant growth components. In the present paper, the correlation and path coefficients have been evaluated to estimate the contribution of plant growth components on grain yield and their association in soybean 
crop.

\section{Materials and Methods}

The secondary data were taken from field experiment which was carried out during Kharif season of 2016-17 at the All India coordinated research project on weed management Department of Agronomy, Dr. Panjabrao Deshmukh Krishi Vidyapeeth Akola, situated at the latitude of $22^{\circ} 42^{\prime}$ North and longitude of $77^{\circ} 02^{\prime}$ East and 281.12 meter above the mean sea level. The experiment was laid out in strip plot design with three replications.

The experiment consisted of eighteen treatment combinations, comprising of six various tillage practices and three weed management practices. The treatments were randomly allotted in each replication. The soybean variety under the study is JS-335.

Five plants were randomly selected from each experimental unit and data were collected on different growth components, viz., dry matter, leaf area index plant ${ }^{-1}$, plant height $(\mathrm{cm})$, number of grain plants ${ }^{-1}$, weight of grain $\left(\mathrm{g} \mathrm{plant}^{-1}\right)$, number of branches plant ${ }^{1}$ and number of pods plant ${ }^{-1}$ etc. Biological yield was recorded after the harvest of the crop.

\section{Correlation coefficient}

The linear relationship between two variable $\mathrm{x}$ and $\mathrm{y}$ cam be estimated by using Karl Pearson's coefficient of correlation $\left(\mathrm{r}_{\mathrm{xy}}\right)$. It is based on the variance and covariance of the variables. It is given by

$$
\mathrm{r}_{\mathrm{xy}}=\frac{\operatorname{Cov}(x, y)}{\sqrt{v(x)} \sqrt{v(y)}}
$$

Variance and covariance is calculated by following formulae:-

$$
\begin{aligned}
\mathrm{V}(\mathrm{x}) & =\frac{1}{n}\left[\sum x^{2}-\frac{\left(\sum x\right)^{2}}{n}\right] ; \\
\mathrm{V}(\mathrm{y}) & =\frac{1}{n}\left[\sum y^{2}-\frac{\left(\sum y\right)^{2}}{n}\right] ; \\
\operatorname{cov}(\mathrm{x}, \mathrm{y}) & =\frac{1}{n}\left[\sum x y-\frac{\left(\sum x\right)\left(\sum y\right)}{n}\right]
\end{aligned}
$$

To test the significance of correlation coefficient, $\mathrm{t}$ test is used and calculated $\mathrm{t}$ value can be compared with tabulated t value at $\alpha$ level of significance with (n-2) degree of freedom. (Cochron and Snedecor, 1967).

$$
\mathrm{t}_{\mathrm{cal}}=\frac{r \sqrt{n-2}}{\sqrt{1-r^{2}}}
$$

\section{Path coefficients analysis}

Path coefficient analysis is a technique by which we can divide the correlation coefficients into direct and indirect effects. The variables under the study are classified as dependent variable and independent variables.

The dependent variable (grain yield) is supposed to be influenced by the other characters called independent variables (growth components). The path coefficient is estimated by solving following set of simultaneous equations representing the basic relationship between correlation and path coefficients.

$r_{i y}=r_{i 1} P_{1 y}+r_{i 2} P_{2 y}+\ldots \ldots . .+r_{i, n} P_{n y} i=1,2,3, \ldots, n$

Where, $\mathrm{n}$ is the number of independent variables (causes); $r_{1 y}$ to $r_{n y}$ denote the coefficients of correlation among all possible combinations of causal factors and $\mathrm{P}_{1 \mathrm{y}}$ to $\mathrm{P}_{\mathrm{ny}}$ denote the direct effects of the character 1 to $\mathrm{i}$ on the character y respectively. The indirect effect of $i^{\text {th }}$ variable through $j^{\text {th }}$ variable on $y$ dependent variable is computed as $\mathrm{P}_{\mathrm{jy}} \times \mathrm{r}_{\mathrm{ji}}$ 
The above equations can be written in the form of the following matrix:

$\mathrm{R}=\mathrm{CP}$

$$
\left(\begin{array}{c}
r_{1 y} \\
r_{2 y} \\
\vdots \\
r_{n y}
\end{array}\right)=\left(\begin{array}{cccc}
r_{11} & r_{12} & \cdots & r_{1 n} \\
r_{21} & r_{22} & \cdots & r_{2 n} \\
\vdots & \vdots & \vdots & \vdots \\
r_{n 1} & r_{n 2} & \cdots & r_{n n}
\end{array}\right)\left(\begin{array}{c}
P_{1 y} \\
P_{2 y} \\
\vdots \\
P n y
\end{array}\right)
$$

$\mathrm{P}=\mathrm{C}^{-1} \mathrm{R}$

Let $\mathrm{C}^{-1}=\left(\begin{array}{cccc}c_{11} & c_{12} & \cdots & c_{1 n} \\ c_{21} & c_{22} & \cdots & c_{2 n} \\ \vdots & \vdots & \cdots & \vdots \\ c_{n 1} & c_{n 2} & \cdots & c_{n n}\end{array}\right)$

Path coefficients are estimated as follows:

$$
\mathrm{P}_{1 \mathrm{y}}=\sum c_{1 i} r_{i y}, \mathrm{P}_{2 \mathrm{y}}=\sum c_{2 i} r_{i y} \text { etc. }
$$

The effect of residual factor (z) which measures the contribution of remaining characters not included in the path coefficient analysis is estimated as follows:

$$
\mathrm{P}_{\mathrm{YZ}}=\sqrt{1-R^{2}}
$$

Where, $\mathrm{R}^{2}$ is coefficient of determination.

$$
\mathrm{R}^{2}=\mathrm{P}_{\mathrm{y} 1} \mathrm{r}_{\mathrm{y} 1}+\mathrm{P}_{\mathrm{y} 2} \mathrm{r}_{\mathrm{y} 2}+\ldots \ldots+\mathrm{P}_{\mathrm{yn}} \mathrm{r}_{\mathrm{yn}}
$$

Standard errors for the path coefficient are given as

$$
\mathrm{SE}\left(\mathrm{P}_{\mathrm{yi}}\right)=\sqrt{c_{j j}} \sqrt{s_{e}^{2}}
$$

Where $s_{\theta}^{2}=\frac{1-R^{2}}{n-p-1}$

$\mathrm{P}=$ Number of causal factors

$\mathrm{n}=$ Number of observations

$\mathrm{c}_{\mathrm{jj}}=$ Diagonal values in the inverse of the correlation matrix

To test the significance of the path coefficients we use the t-test

$$
t_{i}=\frac{P_{y i}}{S E\left(P_{y i}\right)} \text { with (n-p-1) d.f. }
$$

\section{Results and Discussion}

\section{Estimates of inter character correlations}

The several growth components or characters understudy may have correlation with each other that eventually affects the yield. That association may be either in a positive or negative direction. The value of Karl Pearson's correlation coefficient (r) helps in finding the correlation between two characters. If the correlation coefficient is nearer to -1 or +1 , it indicates high degree of the linear relationship between them. If it is nearer to zero then there is no linear relationship. Table 1 shows the inter-character correlations among grain yield(GY), number of grain per plant(NG), number of pods per plant(NP), LAI, plant height(PH), weight of grain per plant(WG), number of branches per plant (NB) and biological yield(BY).

The study of correlation coefficient from Table 4.42 reveals that the number of pods per plant $\left(\mathrm{r}=0.649^{* *}\right)$, the number of grains per plant $(\mathrm{r}=0.592 * *)$ and the number of branches per plant $(\mathrm{r}=0.798 * *)$ are significantly correlated with grain yield. NP and NG are also highly correlated with other causal characters except plant height, WG, $\mathrm{BY}$ and $\mathrm{PH}$ which show non-significant correlations with grain yield.

\section{Path coefficient analysis}

Path coefficient analysis of the above said data was also carried out to study the direct and indirect effects. The results are given in Table 2 which shows that number of branches per plant has the maximum direct positive effect (0.6561) on grain yield. This is followed by number of pods per plant (0.3204), number of grains per plant (0.1488) 
and Plant height (0.0948). Weight of grains per plant (-0.297), LAI (-0.072) and biological yield (-0.0207)have negative direct effect on grain yield. NB showed higher indirect positive effects on grain yield through other casual characters. The indirect effects of $\mathrm{NP}, \mathrm{NG}, \mathrm{PH}$, and $\mathrm{NB}$ on grain yield through other characters are observed to be positive. WG showed an indirect negative effect on grain yield through all other characters but LAI revealed an indirect negative effect on grain yield through all characters except BY. Similarly, the indirect effects of BY on grain yield through other characters are found to be negative except LAI for which it has positive effect on grain yield. The results obtained from correlation and path coefficient analysis strongly indicate that number of branches per plant, no. of pods per plant and no. of grains per plant should be considered as indices for selecting high yielding soybean variety.

Table.1 Pearson Correlation Coefficients

\begin{tabular}{|c|c|c|c|c|c|c|c|c|}
\hline & GY & NP & NG & WG & LAI & PH & NB & BY \\
\hline \multirow[t]{2}{*}{ GY } & 1 & $.649 * *$ & $.592 * *$ & .227 & $.352^{* *}$ & .268 & $.798 * *$ & .197 \\
\hline & & .000 & .000 & .099 & .009 & .050 & .000 & .154 \\
\hline \multirow[t]{2}{*}{ NP } & & 1 & $.653 * *$ & $.533 * *$ & $.402 * *$ & .064 & $.641 * *$ & $.349 * *$ \\
\hline & & & .000 & .000 & .003 & .645 & .000 & .010 \\
\hline \multirow[t]{2}{*}{ NG } & & & 1 & $.536^{* *}$ & $.366^{* *}$ & .090 & $.640 * *$ & $.416^{* * *}$ \\
\hline & & & & .000 & .006 & .517 & .000 & .002 \\
\hline \multirow[t]{2}{*}{ WG } & & & & 1 & $.389 * *$ & .003 & $.468 * *$ & .260 \\
\hline & & & & & .004 & .983 & .000 & .058 \\
\hline \multirow[t]{2}{*}{ LAI } & & & & & 1 & .135 & $.523^{* *}$ & -.062 \\
\hline & & & & & & .331 & .000 & .654 \\
\hline \multirow[t]{2}{*}{ PH } & & & & & & 1 & .230 & .042 \\
\hline & & & & & & & .095 & .764 \\
\hline \multirow[t]{2}{*}{ NB } & & & & & & & 1 & .171 \\
\hline & & & & & & & & .215 \\
\hline \multirow[t]{2}{*}{ BY } & & & & & & & & 1 \\
\hline & & & & & & & & \\
\hline
\end{tabular}

Correlation is significant at the 0.01 level (2-tailed) 
Table.2 Path Coefficients Showing Direct and Indirect Effect for Grain Yield

\begin{tabular}{|l|l|l|l|l|l|l|l|l|l|l|}
\hline Sr.No. & $\begin{array}{l}\text { Char- } \\
\text { acter }\end{array}$ & r with GY & $\begin{array}{l}\text { Direct } \\
\text { Effect }\end{array}$ & \multicolumn{2}{l}{ Indirect Effect } \\
& & & & NP & NG & WG & LAI & PH & NB & BY \\
\hline $\mathbf{1}$ & NP & 0.6492 & 0.3204 & 0.3206 & 0.209 & 0.171 & 0.129 & 0.0205 & 0.2056 & 0.112 \\
\hline $\mathbf{2}$ & NG & 0.5915 & 0.1488 & 0.0971 & 0.149 & 0.079 & 0.055 & 0.0134 & 0.0952 & 0.0519 \\
\hline $\mathbf{3}$ & WG & 0.227 & -0.297 & -0.159 & -0.159 & -0.297 & -0.116 & -0.0009 & -0.139 & -0.077 \\
\hline $\mathbf{4}$ & LAI & 0.3522 & -0.072 & -0.03 & -0.026 & -0.028 & -0.072 & -0.009 & -0.038 & 0.0045 \\
\hline $\mathbf{5}$ & $\mathbf{P H}$ & 0.2678 & 0.0948 & 0.006 & 0.008 & 0.0003 & 0.013 & 0.0948 & 0.0217 & 0.016 \\
\hline $\mathbf{6}$ & $\mathbf{N B}$ & 0.797 & 0.6561 & 0.421 & 0.419 & 0.307 & 0.343 & 0.151 & 0.6561 & 0.1125 \\
\hline $\mathbf{7}$ & $\mathbf{B Y}$ & 0.1967 & -0.0207 & -0.007 & -0.009 & -0.0054 & 0.0013 & -0.0008 & -0.0035 & -0.0207 \\
\hline
\end{tabular}

Residual factor $=\sqrt{0.252244}=0.502238$

The correlation and path coefficient analysis were carried out to analyze the interrelationship between plant growth components and grain yield of soybean variety JS-335.The results obtained from correlation and path coefficient analysis strongly reveal that the number of pods per plant $\left(\mathrm{r}=0.649^{* *}\right)$, the number of grains per plant $(\mathrm{r}=0.592 * *)$ and the number of branches per plant $(\mathrm{r}=0.798 * *)$ are highly correlated with grain yield. Path coefficient analysis indicates that the number of branches plant ${ }^{-1}$ has the maximum direct positive effect $(0.6561)$ on grain yield. This is followed by number of pod plant ${ }^{-1}(0.3204)$ and number of grains plant ${ }^{-1}(0.1488)$. Therefore, number of branches plant ${ }^{-1}$, no. of pods plant ${ }^{-1}$ and no. of grains plant ${ }^{-1}$ should be considered as indices for selecting high yielding soybean variety.

\section{References}

Agarwal, D. K., Billore, S.D., Sharma, A. N., Dupare B. U., and Srivastava. (2013). Soybean: Introduction, improvement and utilization problem in IndiaProblems and Prospects, Agricultural Research, 2(4):293-300.
Aondover, S., Bello, L. and Vange, T.(2013).Correlation, path coefficient and principal component analysis of seed yield in soybean genotypes, International Journal of Advanced Research,1(7):1-5.

Arshad, M., Ali, N. And Ghafoor, A. (2006). Character correlation and path coefficient in soybean Glycine max (L.) Merrill,Pak. J. Bot., 38(1):121-130, 2006.

Cyprien, M. and Kumr, V. (2011) Correlation and path coefficient analysis of ricecultivars data,Journal of Reliability and Statistical Studies, 4(2):119-131.

Dewey, D.R., Lu, K. H. (1959). A correlation and path coefficient analysis of componentscrested wheat grass and seed production, Agronomy Journal, 52:515-518.

Dvorjak, D., Unêda-Trevisoli, S., Leite, W., Silva, A., Silva, F., \& Mauro, A. (2019). Correlations and path analysis in soybean progenies with resistance source to cyst nematode (race 3), Comunicata Scientiae, 10(1):168175.

Iqbal, S., Mahmood, T., Tahira, M., Ali, M. 
and Sarwar, M. (2003). Path analysis in mash (Vignamungo L.), Pak. J. Bot., 22(2):160-167.

Johnson, H.W., Robinson, H.F. and Comstock, R.E.(1955). Genotypic and phenotypic correlations in soybeans and their implication in selection, Agronomy Journal, 47(10):477-483.

Magashi, A., Shawai, R. S., Muhammad, A. and Abdulkadir A. U. (2018). The relationship among some quantitative characters of different varieties of soyabean (Glycine max (L) Merrill.) in the Sudan Savannah Agro-Ecological Zone of Nigeria, International Journal of Advances in Scientific Research and Engineering (ijasre), 4(8): 36-40.

Mauricio,F., Carvalho, Ricardo, I, Pelegrin, D., Junior, A. and Maicon.(2018).Path analysis and phenotypic correlation among yield components of soybean using environmental stratification methods, Australian Journal of Crop Science, 12(2):193-202.

Patil, H.S. and Deshmukh, R.B.(1989). Correlation and path analysis in black gram, Journal of Maharashtra Agriculture University, 14:310-312.

Shamsi, K. (2009). The effects of planting density on grain filling, yield and yield components of chick pea (Cicerarietinum L.) varieties in Kermanshah, Iran, Journal of Animal and Plant Sciences, 2(3):99-103.

Snedecor, G. W. and Cochran, W. G. (1956)Statistical methods applied to experiments in agriculture and biology. 5th ed. Ames, Iowa: Iowa State University Press.

Sohel, H. M., M., Rasel, M., Shaikh, Jafar M. and Sajjadul, A. K. M. (2016). Correlation and path coefficient analysis of Blackgram (VignamungoL.),Journal of Bioscience Agriculture Research,07 (02): 621-629.

Steve, M., Zaher, K., Tomie, G. and Željko J.(2019). Path analysis of drought tolerant maize hybrid yield and yield components across planting dates, Journal of Central European Agriculture, 20(1), 194-207.

Udensi, O. and Ikpeme (2012). Correlation and Path Analyses of Seed Yield and its contributing Traints in Cajanuscajan (L) Millsp,AmericanJournal of Experimental Agriculture,2(3):351$358,2012$.

Wright S. (1921).Correlation and causation, Journal of Agricultural Research, 20(7):557-585.

\section{How to cite this article:}

Agashe Nehatai Wamanrao, Vinod Kumar and Dronkumar Meshram. 2020. Correlation and Path Coefficient Analysis of Grain Yield and its Growth Components in Soybean (Glycine max. L.). Int.J.Curr.Microbiol.App.Sci. 9(03): 2445-2451.

doi: https://doi.org/10.20546/ijcmas.2020.903.280 